\title{
Landscape valuation of historical tourism site in Northern Iran: A case study from Sheikh-Zahed Tomb
}

\author{
Ghazaleh Jahandideh-Kodehi ${ }^{1}$ - Mohammad Kavoosi-Kalashami ${ }^{1 凶}-$ Mohammad \\ Karim Motamed ${ }^{1}$ \\ ${ }^{1}$ Department of Agricultural Economics, University of Guilan, Rasht, Iran \\ ${ }^{\otimes}$ mavoosi@guilan.ac.ir
}

\begin{abstract}
In Iran, the importance of landscapes and the need to preserve these unique assets is not particularly recognized especially at tourism and environmental sites. This study investigated the landscape valuation of Sheikh-Zahed Tomb in Northern Iran. The contingent valuation method (CVM), which is based on a survey model, was used to assess visitors' willingness to pay (WTP) in order to preserve the landscape. The data used in this study were collected though face-to-face interviews with 157 visitors to a historic tomb in the first half of 2019. The results indicate that the average of respondents' WTP to preserve the landscape was 0.47 \$ per year. The annual total economic value (TEV) of the landscape is estimated to be 11960782 \$. Respondents' age, monthly income of the respondent's household, the tomb accessibility, the tomb architectural attraction, and proposed price for the landscape preservation had significant effects on WTP. Proposed empirical model (CVM) provides a comprehensive framework for illustrating landscape valuation of natural heritages and historical tourism sites globally as well as in Iran.
\end{abstract}

\section{Keywords}

Contingent valuation method (CVM), landscape valuation, tourism site,

Northern Iran

Received:

12 January 2021

Received in revised form: 21 May 2021

Accepted: 28 May 2021

\section{Introduction}

\subsection{Tourism value in natural and cultural landscapes}

Natural landscapes have many benefits for human beings like feeling belonging to a particular place, having fun, enjoying the scenery, relaxing and recovering (Yi et al. 2016). Natural features are concerned with the natural aspects of a site including climate, soil, mineral resources, landscapes, and etc. These features of the natural landscape provide the place within which human functions occurred (Molaei-Hashjin 2006). In today's world, one of the main goals of planners and politicians is to improve the quality of people's life. One way to achieve this goal is to encourage people to go for natural scenery and recreational activities as part of a modern lifestyle. Hence, it can be concluded that natural landscapes have the potential to create social and economic benefits for communities (Ma \& Sun, 2001). Landscapes are also referred to as social-ecological systems, because in this sense, all aspects of the environment, social and economic are directly related and intertwined (Berkes et al. 2003). In addition, there are natural and cultural landscapes that bring various benefits to their visitors, which can be moral, national or religious, and are basically referred to as socio-cultural 
values (Alcamo 2003). In the Millennium Ecosystem (2005), landscape considered as a supplier of ecosystem service. The environmental landscape is subject to continuous change and perceiving, using, exploiting and managing nature by humanbeing remains as the fundamental challenges in sustainable development goals (Arias-Maldonado 2016; Folke et al. 2016).

Landscapes are considered as exceptional and noncompetitive goods due to their special nature (Lifran \& Oueslati 2007). The demand for landscape is not systematically stated in a market, because it is a non-market good (Rambonilaz 2004). Landscapes can also be a good driver of economic growth (Aznar 2002). These effects on economic growth can potentially, directly or indirectly, come from natural and historical landscapes (Hueting et al. 1998). Policy-makers, stakeholders and planners emphasized on understanding the value that landscape has for human societies. Effective incentive system implementation and achieving landscape quality objectives for landscape planning and management are examples of this necessity (Council of Europe 2000). The complexity of landscapes components challenged economists in assigning monetary values on the landscape (Fry et al. 2007).

Landscapes cannot be considered as other economic goods and due to their special structure, they cannot be traded in the market, for example (Hanley \& Barbier 2009). Unfortunately, due to the deep and widespread destruction of natural landscapes in recent decades, access to and use of these landscapes for humans has been limited and severely reduced. Excessive and unprincipled exploitation of natural resources has caused many environmental problems. That is why environmentalists, governments and the private sector are forced to incorporate natural capital into the socio-economic system (Brown \& Nawas 1973). This process would sustain the ecosystem services supply and maximize their benefits to increase human-being welfare (Ma \& Sun 2001; Lee \& Han 2002; Preez \& Hosking 2010).

\subsection{Monetary landscape valuation}

Tourism contributes to the local economy and support to preserve different aspects of the landscapes (Prince 2019). Nowadays, sustainable tourism motivated by regional planners and policy makers in many countries which insist on the tourists' pleasure, tourism incentives and protection of the physical and old-fashioned fundamentals of the landscape (Insch 2020). For local inhabitants who live around the landscapes, tourism becoming a part of the daily life (Atik et al. 2015). Preserving the landscapes could help the local economies to develop infrastructures (hotels and tourism settlements, transport and IT services) by boosting tourism activities. Landscape denotes the first and most long-term medium of interaction between traveler and prospective or consumed place of travel (Terkenli 2000). There are many aspects and trends in studies related to landscape and tourism but cultural heritage, geotourism, planning, sustainability and environment are common themes in these studies (Jimenez-Garcia et al. 2020). Landscape valuation focused on tourists' welfare and utility, by combining keywords like tourism sustainability and environment in landscape preservation. The total economic value (TEV) provides a comprehensive framework of the economic value for any environmental assets or ecosystem services like landscape (Walsh et al. 1984; Daily 1997; Oueslati et al. 2008; Turner \& Schaafsma 2015). The TEV can be divided into use and non-use values (Turner 1999). Use value is the benefits that come directly from the natural landscape and are used, such as the entertainment that is done through these landscapes. This is while non-use values refer to the value or use that may be used in the future of landscapes, such as the power of choice and existence (Greenley et al. 1981).

In economics, money is used as a general unit of measurement to express the benefits of services provided by ecosystems to humans. There are several ways to translate values in economics into common monetary terms. These methods are universally acclaimed and are recognized as a practical and reliable tool for evaluating ecosystem services. Monetary valuation methods have many advantages, including: the ability to distribute benefits, help solve problems and transactions, and most importantly, a suitable criterion for policy makers to make decisions (Hermann et al. 2011). Also, monetary valuation techniques had serious disadvantages that may lead to bias in estimating true WTP or Willingness to Accept (WTA) (Chomitz et al. 2005). Market imperfections, policy failures, market prices distortion and price variations were among the main disadvantages of these techniques (Cavatassi 2004).

Natural resource valuation theories gradually matured. The travel cost method (TCM) was widely used by experts to evaluate the economic value of tourism resources such as forest parks between the 1970s and 1980s (Willis \& Garrod 1991). After 1980 , experts began using the CVM method to research WTP in the field of environment and natural resources (Caulkins et al. 1986). After this pe- 
riod, in order to price and determine the value of the tourism industry, a method called hedonic price (HPM) was used. In recent years, scientists have combined the two methods of TCM and CVM and taken steps to value natural and environmental resources (Blakemore \& William 2008; Loomis et al. 2008; Yi et al. 2016). In order to evaluate the TEV index for environmental and natural resources projects, the CVM method is the best option available (Ahlheim et al. 2015). In order to focus on users of natural and environmental goods, TCM or HPM methods are highly recommended, but if the use is passive, these two methods will not be suitable (Ahlheim \& Frör 2003). In summary, when environmental goods produce a passive use such as landscaping, it is preferable to use direct WTP retrieval methods such as the CVM method (Loomis et al. 2000). Also, main disadvantages of CVM were external validation, inconsistency in case of rational choice and unreal stated intentions of WTP (Turner \& Schaafsma 2015).

Assessments and protection of natural and environmental resources will play a decisive role in their management, as well as how people feel about these resources (Yi et al. 2016). CVM was used for valuation of agriculture and forest landscapes (Colson \& Stenger 1996; Bonnieux \& LeGoffe 1997; Bonnieux 1998; Point et al. 2007; Hanley et al. 2009), natural landscapes (Bergstrom et al., 1990; Willis and Garrod, 1992; Willis and Garrod, 1993; O'riordan et al. 1993; Yi et al. 2016), wind farm landscapes (Scherrer 2001; Terra 2004; Terra \& Fleuret 2009), urban green spaces (Oueslati et al. 2008; Caula et al. 2009) and urban and architectural landscapes (Prigent 2001).

Many studies have acknowledged that multipurpose landscapes are both more environmentally sustainable and socio-culturally preferred. But landscapes that offer only a few of services are not economically viable (Balmford et al. 2002; Turner et al. 2003; Naidoo \& Adamowicz 2005). Landscapes are generally used for recreational and tourism purposes around the world, and this is their main use (Zamorshchikova et al. 2018).

Landscape converts a public edge where native and worldwide perspectives and other scopes of tourism studies come together in the ready construction and consumption of place identity (Terkenli 2000). The invasion to natural landscapes in the rural areas of the northern provinces of Iran, with the aim of promoting tourism, had no prospects other than destruction of natural resources, destroying the indigenous rural economy and inequality at various social levels. Land use change and environmental degradation in villages of northern Iran have changed the face of these villages. Unawareness toward the value of ecosystem services, especially the value of natural landscapes for society, has challenged proper policymaking in this area. At the heart of the lush mountains in Lahijan County, Northern Iran, next to the tea and citrus orchards, there is a turquoise-colored dome with a beautiful natural landscape that is the tomb of Sheikh-Zahed. The development of tourism centers and villas around the tomb without considering tourism sustainability and proper environmental planning had endangered its natural and architectural landscape. The main goal of this study was to determine the total economic value of preserving the landscape of Sheikh-Zahed tomb, Northern Iran. Also, investigating the effective variables on visitors' WTP for the landscape preservation was another important goal of the study.

\section{Methodology}

\subsection{Area of Study}

Guilan Province is one of the northern provinces of Iran and situated in the South of the Caspian Sea (Fig. 1). This province with an area of 14700 square kilometers and 16 counties is about $0.9 \%$ of the total area of Iran. Lahijan County with an area of 407 square kilometers is located in the east of Guilan province and is considered one of the most beautiful areas of this province (Guilan Province Management and Planning Organization, 2021).

The tomb of Sheikh Zahed is located on the outskirts of Lahijan City. This building is considered to be the burial place of Sheikh Tajuddin Ibrahim, nicknamed Sheikh Zahed, one of the great mystics and dervishes. This building has a dome of eight turquoise cracks and is surrounded by rice, tea and forest fields and is one of the tourist destinations of Guilan province.

\section{Material and methods}

Monetary terms are able to measure changes in individual utility, for which the Hicks's Compensating Variation (HCV) is appropriate. This indicator shows a person's willingness to pay in order to obtain the desired product or the willingness to accept compensation for giving up the pleasure of that product (Ahlheim 1998). The amount of WTP is not visible for goods such as environmental goods because these goods are not traded in the market. 


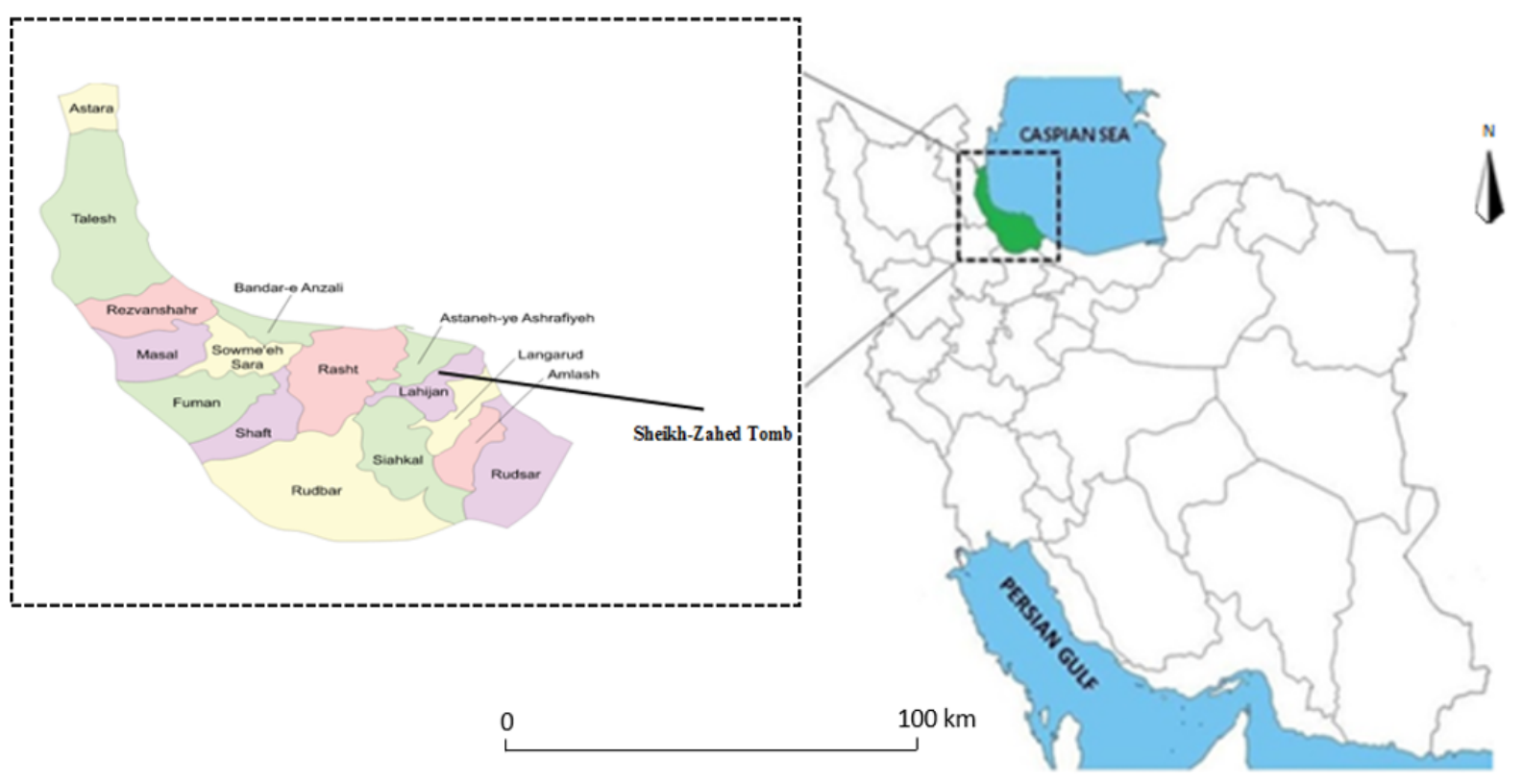

Fig. 1 Location of Guilan Province, Lahijan County \& Sheikh-Zahed Tomb in Iran

Due to the lack of a market for the sale of these goods, as well as the special structure of these goods, researchers have to resort to unique methods to calculate WTP (Ahlheim et al. 2015).

CVM is an efficient method of assessing the value of environmental goods that is generally accepted and estimates the monetary value of goods under the conditions of a hypothetical market (Carson \& Mitchell 1993; Garrod \& Willis 1999). In this method, interviews are conducted with specific individuals to determine the value of an environmental asset (Birol et al. 2006). In this method, the goal is to measure the value of recreational activities and welfare facilities. For this purpose, the amount of WTP of different people in order to use environmental and natural resources will be evaluated (Jim \& Chen 2006). In general, to implement the CVM method, it is necessary to use a questionnaire and complete it by the general public who use a special recreational situation. In this way, information about the value of use, the value of choice and the existential value of those amenities will be fully obtained. All of these values point to the possibility of passive values in relation to those amenities (Birol et al. 2006). The values discussed seek to assess the inherent willingness of individuals to pay to use a particular natural landscape in the present and the future, as well as their desire to preserve that landscape for the future generations (Nijkamp et al. 2008).

The CVM has two important advantages: (i) it enable to evaluate the WTP of people in situations where the quality of environmental recreational fa- cilities may change hypothetically and also in the current and real conditions is widely applicable (Liu 2007); (ii) it is the only available method to determine the non-use value of environmental recreational facilities is CVM because it includes the views of both users and non-users in its calculations (Carson \& Mitchell 1993). By valuing landscape as an entity, CVM avoids many of the problems, such as those of separability and collinearity, often associated with TCM and HPM of landscape valuation (Willis \& Garrod 1993).

Face-to-face interviews are commonly used to collect WTP data from individuals (Yi et al., 2016). In this study, we also used face-to-face interviews with visitors to the tomb of Sheikh Zahed. The questionnaire includes five parts: visitor's socioeconomic characteristic and travel information, explanatory variables and travel motives, the reasons for selecting rural tourism site and most important activities during travel in these areas, visitors' satisfaction from different aspect of travel and the tourism site, ultimately, the last section dealt with valuation scenario to preserve the landscape and visitors' WTP.

In CVM, the continuous and discrete methods were used to extract individuals' WTP. In the continuous method, open end payment cards and suggested game methods are assigned to WTP. In the discrete method, a price is given to the user and he/she is asked to offer his positive or negative answer in the form of two options, multiple and multidimensional options (Tkac 2002). As the stated WTP in double dichotomous choices (DDC) was greater 
than in the open-ended (OE) approach (Kealy \& Turner 1993; Kriström 1993), in valuation scenario, DDC question were used to estimate visitors' WTP for preserving the landscape. In the DDC, a further bid than initial bid must be made. This further bid completely depends on the reaction of respondent or his/her yes or no answer to the first bid (Marta-Pedroso et al. 2007). In valuation scenario, the three bids of $0.56,1.13$ and 2.26 \$ were presented as three interrelated questions. In the first question to the respondent, an average bid of 1.13 $\$$ was offered. The respondent was asked "Are you willing to pay $1.13 \$$ as annual extra tax to preserve the landscape of Sheikh-Zahed tomb?" because this site supplies you a place for recreation and leisure and had many non-use values. If the visitor's answer was "No", then the lower bid of 0.56 $\$$ was proposed and if the answer was "Yes", then the upper bid of 2.26 \$ was offered. In this study, the dependent variable for determining the value of landscape was the probability of acceptance of the bid by the respondents. For this purpose, logit multivariate regression was used to investigate the amount and intensity of the effect of explanatory variables on the dependent variable.

The sample evaluated in this research by CVM method is a representative for all existing projects in the field of environmental goods (Ahlheim et al. 2015). In order to determine the sample size, the method introduced by Carson and Mitchell (1993) was used. Questionnaires were also completed for 4 months (April, June, July and August) at different times in 2019. Research data were obtained after face-to-face interviews with 157 visitors to the mausoleum. Samples were randomly selected from the population of visitors to the Sheikh-Zahed tomb. The main hypotheses of the study were:

- Proposed bids affect the WTP for preserving the landscape of Sheikh-Zahed tomb.

- Demographics (like age \& revenues) of the respondents affect the WTP for preserving the landscape of Sheikh-Zahed tomb.

- Environmental components (like accessibility and architectural attraction) affect the WTP for preserving the landscape of Sheikh-Zahed tomb.

If the visitor utility function is $u=u(h, y$; s) where $\mathrm{y}$ is the visitor's income, $\mathrm{s}$ is the vector of the demographics, and $h$ is one if there is a WTP and zero if there is no WTP. In case the visitor accepts the bid price A to preserve the landscape, her/his indirect utility function can be written as follows (Hanemann 1984):

$$
v(1, y-A ; s)+e_{1}>v(0, y-A ; s)+e_{0}
$$

The probability of WTP $\left(\mathrm{P}_{1}\right)$ and its absence $\left(\mathrm{P}_{0}\right)$ can be written as follows (Park \& Loomis, 1996):

$$
\begin{aligned}
P_{1} & =\operatorname{Pr}\{W T P\} \\
& =v(1, y-A ; s)+e_{!}>v(0, y-A ; s)+e_{0} \\
P_{0} & =1-P_{1}
\end{aligned}
$$

Assuming $n=e_{0}-e_{1}$ and using the cumulative distribution function, we have (Hanemann 1984):

$$
\begin{aligned}
P_{1} & =F_{n}(d v) \\
& =F_{n}(v(0, y-A ; s)-v(1, y-A ; s)+n)
\end{aligned}
$$

Where, $d v$ shows the difference between indirect utilities in the presence of WTP and its absence. Assuming a logistic distribution for $\mathrm{F}_{\mathrm{n}}($.$) and a lin-$ ear functional form for the utility function, we have (Park \& Loomis, 1996):

$$
P_{1}=F_{n}(d v)=\left(1+\exp \left(\left(a_{0}-a_{1}\right)+b A+n\right)\right)^{-1}
$$

Where, $\left(a_{0}-a_{1}\right)$ is the difference between the constants of the indirect utility functions and $b$ is the coefficient of the bid. In this case, the probability of WTP is only a function of the bid for the landscape preservation. The maximum WTP of the visitor is the amount that her/his utility under WTP and its absence was equal, i.e. $d v=0$ (Samdin 2008). So, we have:

$$
\text { Max WTP }=-\frac{\left(a_{0}-a_{1}\right)}{b}
$$

The empirical model used to estimate the WTP function is as follows:

$$
W T P=f(B i d, A g e, R E V, A C S, A G S)
$$

In equation (6), proposed price for preservation of the landscape (Bid), age of respondent (Age), monthly income of respondent's household (REV), respondent's score in accessibility component of the landscape (ACS) and respondent's score in architectural attraction component of the landscape (AGS), were considered as explanatory variables.

After estimating the WTP function based on the estimated coefficient for the constant and the Bid variable, the maximum WTP of the visitor for preserving the landscape was calculated. Besides estimating visitors' WTP for the landscape preservation, their motivations for tourism, preferred activities during travel and satisfaction by different 
tourism elements, were investigated. Considering travel motivations and satisfaction could help to provide additional control variables in valuation model of the landscape.

\section{Results and discussion}

Out of 157 respondents who participated in this survey, 72 (46\%) and 85 (54\%) individuals were males and females, respectively. Only 24 (15.29\%) respondents were native (live in Guilan Province) and the other ones travel to Lahijan County from different Iran's provinces. Descriptive statistics of respondents' socio-economic characteristics was shown in Table 1.

Table 1 Descriptive statistics of respondents' socio-economic characteristics $(\mathrm{n}=157)$

\begin{tabular}{llllll}
\hline \multicolumn{1}{c}{ Variables } & \multicolumn{2}{c}{$\begin{array}{c}\text { Frequency } \\
(\%)\end{array}$} & Average & S.D. \\
Age (Year) & - & 38.74 & 10.12 \\
\hline $\begin{array}{l}\text { Household size } \\
\text { (number of members) }\end{array}$ & - & 3.88 & 1.28 \\
\hline \multirow{2}{*}{ Education } & Diploma Diploma & 3.18 & & \\
& Academic & 18.47 & - & - \\
\hline Monthly & $<2$ & 78.35 & & \\
Household's & $2-4$ & 49.04 & & \\
Income & $>4$ & 38.22 & - & - \\
\hline
\end{tabular}

* Million Rials

In order to assess travel information of the respondents four parameters include travel costs, annual number of travels to Lahijan County, traveling in special times and type of travel were investigated. Descriptive statistics of respondents' travel information was shown in Table 2.

Table 2 Descriptive statistics of respondents' travel information $(\mathrm{n}=157)$

\begin{tabular}{|c|c|c|c|}
\hline Variables & \multicolumn{3}{|c|}{ Frequency (\%) Average S.D. } \\
\hline Travel costs Native & 15.29 & 86042 & 64183 \\
\hline (10 Rials) Non-native & 84.71 & 436917 & 404531 \\
\hline $\begin{array}{l}\text { Annual number of } \\
\text { travels to Lahijan County }\end{array}$ & - & 1.99 & 1.09 \\
\hline \multirow{2}{*}{$\begin{array}{l}\text { Traveling in } \\
\text { special times }\end{array}$} & 31.21 & \multirow[b]{2}{*}{ - } & \multirow{2}{*}{ - } \\
\hline & 68.79 & & \\
\hline \multirow{3}{*}{ Type of travel } & 5.73 & \multirow{3}{*}{-} & \multirow{3}{*}{-} \\
\hline & 62.42 & & \\
\hline & 31.85 & & \\
\hline
\end{tabular}

On average, respondents traveled to Lahijan County more than once a year. This showed that Lahijan County is a popular tourism region among understudy respondents. More than $60 \%$ of visitors travel with family and this type of travel ranked first among respondents.

Seven components include faith and self-flowering, religious and cultural attractions, accessibility, getaway and rest, being with family, nature-friendly, and architectural attraction were examined to investigate travel motivations among respondents. The items of these components were planned based on several studies (Arabshahi et al., 2018; Wang et al., 2016; Yousefi \& Marzuki 2015; Battour et al. 2014; Chand 2010). Interval of Standard Deviation from the Mean (ISDM) was used to group the respondents based on the scores they obtained in the mentioned components. Respondents grouped in four grades of A, B, C and D, respectively, as it was shown in Table 3. Group D and $\mathrm{A}$ had the highest and lowest scores in each component, respectively.

Table 3 Grouping respondents based on travel motivation components $(n=157)$

\begin{tabular}{|c|c|c|c|c|c|}
\hline Components & $\begin{array}{l}\text { \# of } \\
\text { items }\end{array}$ & $\begin{array}{c}\text { Group A } \\
(\%)\end{array}$ & $\begin{array}{c}\text { Group B } \\
(\%)\end{array}$ & $\begin{array}{c}\text { Group C } \\
(\%)\end{array}$ & $\begin{array}{c}\text { Group D } \\
(\%)\end{array}$ \\
\hline $\begin{array}{l}\text { Faith and } \\
\text { self-flowering }\end{array}$ & 8 & 11.46 & 31.85 & 44.59 & 12.1 \\
\hline $\begin{array}{l}\text { Religious and } \\
\text { cultural attractions }\end{array}$ & 3 & 11.46 & 59.24 & 15.29 & 14.01 \\
\hline Accessibility & 3 & 12.74 & 37.58 & 39.49 & 10.19 \\
\hline $\begin{array}{l}\text { Getaway } \\
\text { and relaxation }\end{array}$ & 4 & 21.02 & 40.13 & 16.56 & 22.29 \\
\hline $\begin{array}{l}\text { Spending time } \\
\text { with the family }\end{array}$ & 3 & 17.2 & 33.12 & 40.76 & 8.92 \\
\hline Nature-friendly & 3 & 40.13 & 6.37 & 45.86 & 7.64 \\
\hline $\begin{array}{l}\text { Architectural } \\
\text { attraction }\end{array}$ & 3 & 27.39 & 15.92 & 43.31 & 13.38 \\
\hline
\end{tabular}

Results of Table 3 showed that faith and selfflowering and architectural attraction ranked first in tourists motives, nature-friendly motive had second rank and accessibility and being with family named as the third powerful motives for visiting Sheikh-Zahed tomb among respondents. Family togetherness, relaxation, and self-development were the main motives that drive tourists to travel (Pearce \& Lee 2005). Learning, engaging in social contacts (especially with residents), novelty, searching for authenticity and tradition, spending time with the family, and travel costs were found as the most important motives for tourists around the world in recent years (Tyrväinen et al. 2001; 
Jang \& Wu 2006; Molera \& Albaladejo 2007; Park and Yoon, 2009). Also, modeling and gaining experience of cultures, different lifestyles in different eras, hospitality, involving in rural lives, landscapes, outdoor activities, tasting foods and drinks, were among the motives for rural tourism (Cai 2002; Frochot 2005; Royo-Vela 2009; Peasonen \& Komppula 2010; Demirović et al. 2019).

Providing conditions for tourists to perform desired activities in the region can help boost tourism and improve its economic cycle. Tourists' interest in performing 10 different activities in the study area was assessed using Likert scale.

Table 4 Perceived importance of tourism activities for respondents $(n=157)$

\begin{tabular}{lrrr}
\hline Activity & Mean & S.D. & Rank \\
\hline Experiencing local culture and lifestyle & 3.44 & 1.04 & 5 \\
Agricultural experiences & 3.13 & 1.34 & 9 \\
Tasting local foods and drinks & 3.89 & 1.1 & 2 \\
Viewing beautiful natural landscapes & 4.11 & 0.9 & 1 \\
Trekking and hiking in nature & 3.6 & 1.2 & 3 \\
Visiting national, provincial, local parks & 3.43 & 1.21 & 6 \\
Attending local events, markets and festivals & 3.2 & 1.27 & 8 \\
Visiting historical and cultural attractions & 3.51 & 1.15 & 4 \\
Experiencing adventure activities & 3.3 & 1.25 & 7 \\
Water sports & 2.97 & 1.38 & 10 \\
\hline
\end{tabular}

As shown in Table 4, the respondents were highly interested in viewing beautiful natural landscapes. Other preferred activities include tasting local foods and drinks, and hiking or trekking in a nature area. Overall, respondents were the least interested in participating in water sports, agricultural experiences and attending local events, markets and festivals. These results supported the idea of the importance of landscape for tourists. Demirović et al. (2019) showed that live through local culture and lifestyle and be toughly involved in rural life was the most preferred activities in Northern Serbia, but taking adventure activities was the lowest preferred ones by tourists.

Measuring tourists' satisfaction is considered as a tool for tourism growth and competitive advantage. Respondents' satisfaction with empathy and responsibility of host community, perceptible indicators of tourism, the tomb interior, and the sanitation and hygiene were studied. The ISDM was used to group the respondents based on their satisfaction scores in the four mentioned cases. Respondents grouped in four grades of A, B, C and D, respectively, as it was shown in Table 5 . Group $\mathrm{D}$ and $\mathrm{A}$ had the highest and lowest satisfaction scores in each case, respectively. Several studies were used for designing the items of these satisfaction components (Barzegar, 2019; Del $\neg$ Rio et al. 2017; Soltani \& Sharif 2016; Liao et al. 2015).

Table 5 Grouping respondents based on satisfaction scores $(n=157)$

\begin{tabular}{|c|c|c|c|c|c|}
\hline \multirow{2}{*}{ Case } & \multicolumn{5}{|c|}{ \# of Group A Group B Group C Group D } \\
\hline & items & $(\%)$ & $(\%)$ & $(\%)$ & $(\%)$ \\
\hline $\begin{array}{l}\text { Empathy } \\
\text { and responsibility } \\
\text { of host community }\end{array}$ & 5 & 17.83 & 36.31 & 24.84 & 21.02 \\
\hline $\begin{array}{l}\text { Perceptible indicators } \\
\text { of tourism }\end{array}$ & 8 & 13.38 & 35.03 & 30.57 & 21.02 \\
\hline The tomb's interior & 3 & 20.38 & 32.48 & 20.38 & 26.75 \\
\hline $\begin{array}{l}\text { The sanitation } \\
\text { and hygiene }\end{array}$ & 3 & 25.48 & 24.2 & 41.4 & 8.92 \\
\hline
\end{tabular}

Only in two cases of perceptible indicators of tourism, and the sanitation and hygiene, more than $50 \%$ of respondents had higher than average level, satisfaction. High frequency of satisfaction rank in group A and B for different cases showed that tourism management at the regional level does not have a clear strategy for attracting tourists and promoting local tourism sites by improving tourist satisfaction. The response of visitors to the landscape valuation scenarios of SheikhZahed tomb can be summarized in Table 6 .

Table 6 Frequency of visitors' response to valuation scenarios $(\mathrm{n}=157)$

\begin{tabular}{lcrrr}
\hline \multicolumn{4}{l}{ Acceptance/ Rejection Primary bid* } & Lower bid** \\
\hline Bid Acceptance & $\mathrm{N}$ & 33 & 19 & 18 \\
& $\%$ & 21.02 & 15.32 & 54.55 \\
\hline \multirow{2}{*}{ Bid Rejection } & $\mathrm{N}$ & 124 & 105 & 15 \\
& $\%$ & 78.98 & 84.68 & 45.45 \\
\hline Total & $\mathrm{N}$ & 157 & 124 & 33 \\
& $\%$ & 100 & 100 & 100 \\
\hline
\end{tabular}

$* 1.13 \$$ per a year as extra tax

** $0.56 \$$ per a year as extra tax

*** $2.26 \$$ per a year as extra tax

Results showed that 33 visitors had accepted the primary bid and 19 accept the lower bid. So, 52 visitors $(33.12 \%)$ of respondents had WTP (bid acceptance), for the landscape preservation. In order to fit the valuation function, a range of demographic, attitude and motivation explanatory variables was considered. In the final valuation function, statistically significant independent variables included proposed price for preserving the landscape (BID), age of respondent (AGE), monthly income of household (REV), respondent's score in the 
accessibility component of the landscape (ACS) and respondent's score in the architectural attraction component of the landscape (AGS).

Table 7 Valuation model of the landscape $(n=157)$

\begin{tabular}{lrrrrr}
\hline Variable & Coefficient & S.E. & t-stat & Elasticity $\begin{array}{r}\text { Marginal } \\
\text { Effect }\end{array}$ \\
\hline BID & $\begin{array}{r}-0.57 \\
\times 10^{-4}\end{array}$ & $\begin{array}{r}0.15 \\
\times 10^{-4}\end{array}$ & $-3.59^{* * *}$ & -0.35 & $\begin{array}{r}-0.13 \\
\times 10^{-4}\end{array}$ \\
\hline AGE & 0.01 & $\begin{array}{r}0.82 \\
\times 10^{-2}\end{array}$ & $2.37 * *$ & 0.4 & $\begin{array}{r}0.47 \\
\times 10^{-2}\end{array}$ \\
\hline REV & 0.1 & 0.05 & $2.15^{* *}$ & 0.18 & 0.02 \\
\hline ACS & -0.17 & 0.03 & $-5.58^{* * *}$ & -0.78 & -0.04 \\
\hline AGS & 0.17 & 0.04 & $4.03^{* * *}$ & 1.1 & 0.04 \\
\hline Constant & -1.36 & 0.68 & $-1.99 * *$ & - & - \\
\hline LR = 86.64 (0.00) & $\%$ correct prediction $=66 \%$ \\
\hline *** Significant at 1\% level \\
** Significant at 5\% level \\
* Significant at 10\% level
\end{tabular}

In order to examine the overall significance of the regression, the LR statistic was used. Given the probability level (0.00) of this statistic (86.64), the null hypothesis of this test was rejected and the estimated Logit regression was generally significant. Also, the percentage of correct (right) prediction was $66 \%$ which indicates high power of the regression. The LM2 test was used to evaluate the heteroscedasticity of the regression. The probability level (0.81) of the LM2 statistic (5.73) indicated the acceptance of the null hypothesis that means there was no heteroscedasticity in the regression. Also, analysis of variance test was used to investigate the multicollinearity between the explanatory variables of the model. Results showed that there was no strong multicollinearity among independent variables.

The coefficient of BID was negative and statistically significant at $1 \%$. Hence, this variable had an adverse effect on the likelihood of respondents WTP for the conservation of the landscape. As the elasticity showed, a percent increase in BID value caused a $0.35 \%$ decrease in the likelihood of respondents WTP for the landscape preservation. Also, the marginal effect indicated 0.13 decrease in the likelihood of respondents WTP if the BID increase $0.075 \$$. Several studies reported the indirect and significant effect of BIDs (Choi et al. 2016; Ahlheim et al. 2015; Jim \& Chen 2006; Loomis et al. 2000). The effect of respondent age (AGE) and monthly income of respondent's household (REV) on WTP were positive and significant. The similar effect of these variables on WTP re- ported in previous studies like Choi et al. (2016). The negative and significant effect of ACS showed that easy accessibility to the landscape (as it was in the case of Sheikh-Zahed tomb) decrease its value to the respondents. It could be concluded that being pristine and difficult to access will increase the landscape value to people. Architectural attraction of Sheikh-Zahed tomb had positive and significant effect on respondent WTP for the landscape preservation. Choi et al. (2016) insist on this variable positive effect on WTP for preservation.

Using the coefficients of valuation model and the average and median of explanatory variables in this model, the respondent average and median WTP for landscape preservation of Sheikh-Zahed tomb were 0.47 and 0.38 \$ per a year, respectively. Hence, considering 25.6 million households in Iran (Statistical center of Iran 2019) the annual TEV of the landscape per average and median of the WTP were 11960782 and 9808842 \$.

The time and budget constraints in the study did not allow for the increase of sample members to reduce the margin of error. Improving the sampling process by selecting sample members from different cost/revenue deciles can make it less biased in estimating the WTP. Also, sampling in different seasons would lead to the mentioned advantages.

\section{Conclusion}

Determining the value of a natural landscape is of great importance to society and will also bring benefits. This study determined the total value of the tomb of Sheikh-Zahed, located in Lahijan County, northern Iran, using the CVM method. In general, the results of this study are applicable to tomb management as well as local service provider agents.

In order to improve the tourism conditions of the tomb and thereby increase the level of visitors' satisfaction, continuous visits of their comments and suggestions seems necessary. Accordingly, it is necessary to consider new ways of expressing criticism and suggestions of visitors such as social networks, internet sites and so on.

The pristine and original landscape of the tomb is important for respondents. Local managers and authorities should develop a specific plan to prevent widespread land use change and preserve the tomb landscape. The tomb's tourism position, influence by natural and architectural elements preservation in the landscape. Any new development plans that influence on the landscape 
of Sheikh-Zahed tomb should consider the estimated TEV in its cost-benefit analysis.

The low participation rate of respondents in the hypothetical payment scenario to preserve the tomb's landscape $(33.12 \%)$ could be due to the lack of awareness of the importance of landscape preservation in Iranian society. There is no established educational and cultural program on the importance of landscapes and the need to preserve them in Iran. Awareness of the community about landscape functions and the need to preserve it for future generations should be on the agenda, especially in areas with widespread land use changes such as the northern provinces of Iran.

\section{Acknowledgements}

Authors would like to thank the anonymous reviewers and to the journal editors for their careful reading of our manuscript and their many insightful comments and suggestions.

\section{References}

Alcamo J (2003) Ecosystems and human well-being: A framework for assessment, Millennium Ecosystem Assessment Series. Island Press, Washington, DC.

Ahlheim M (1998) Handbook of Utility Theory. In: Barberà S (ed) Kluwer, Dordrecht.

Ahlheim M, Frör O (2003) Valuing the non-market production of agriculture. Agrarwirtschaft 52: 356-369.

Ahlheim M, Frör O, Luo J, Plez S, Jiang T (2015) Toward a comprehensive valuation of water management projects when data availability is incomplete - The use of benefit transfer techniques. Water 7: 1-25.

Arabshahi M, Behbodi O, Kashfi SMA (2018) Analysis of the Role and push and pull Factors in the Development of Religious Tourism in the Holy City of Qom. Journal of Tourism and Development 6(3): 58-79. (In Persian)

Arias-Maldonado M (2016) The anthropogenic turn: Theorizing sustainability in a postnatural age. Sustainability 8(10): 1-17.

Atik M, Isikli RC, Ortacesme V, Yildrim E (2015) Definition of landscape character areas and types in side region, Antalya-Turkey with regard to land use planning. Land Use Policy 44: 90-100.

Aznar O. A (2002) characterization of environmental services with a landscape dimension produced in rural areas. Sustainable Development \& Territories, File 1: Territorial Approaches to Sustainable Development. (In French)

Balmford A, Bruner A, Cooper P, Costanza R, Farber S, Green RE, Jenkins M, Jefferiss P, Jessamy V, Madden J, Munro K, Myers N, Naeem S, Paavola J, Rayment M, Rosendo S, Roughgarden J, Trumper K, Turner RK (2002) Economic reasons for conserving wild nature. Science 297(5583): 950-953.
Barzegar S (2009) Assessing the satisfaction of the quality of the tourist environment (Case study: Gorgan city). Urban Tourism 5(4): 1-18.

Battour M, Ismail MN, Battor M, Awais M (2014) Islamic tourism: an empirical examination of travel motivation and satisfaction in Malaysia. Current Issues in Tourism 20(1): 50-67.

Bergstrom JC, Stoll JR, Titre JP, Wright VL (1990) Economic value of wetlands-based recreation. Ecological Economics 2(2): 129-147.

Berkes F, Colding J, Folke C (2003) Navigating Social-Ecological Systems: Building Resilience for Complexity and Change. Cambridge University Press, New York.

Birol E, Karousakis K, Koundouri P (2006) Using economic valuation techniques to inform water resources management: A survey and critical appraisal of available techniques and an application. Science of the Total Environment 365: 105-122.

Blakemore F, Williams A (2008) British tourists' valuation of a Turkish Beach using contingent valuation and travel cost methods. Journal of Coastal Research 246: 1469-1480.

Bonnieux F (1998) Principles, implementation and limits of the contingent valuation method. Public Economy 1: 47-90. (In French)

Bonnieux F, Le $\neg$ Goffe P (1997) Valuing the Benefits of Landscape Restoration: a Case Study of the Cotentin in Lower-Normandy, France. Journal of Environmental Management 50: 321-333. (In French)

Brown WG, Nawas F (1973) Impact of aggregation on the estimation of outdoor recreation demand functions. American Journal of Agricultural Economics 55(2): 246-249.

Cai LA (2002) Cooperative branding for rural destinations. Annals of Tourism Research 29(3): 720-742.

Carson RT, Mitchell RC (1993) The value of clean water: the public's willingness to pay for boatable, fishable, and swimmable quality water. Water Resources Research 29: 2445-2454

Caula S, Hvenegaard GT, Marty P (2009) The influence of bird information, attitudes and demographics on public preferences toward urban green spaces: The case of Montpellier, France. Urban Forestry \& Urban Greening 8(2): 117-128.

Caulkins PP, Bishop RC, Bouwes NW (1986) The travel cost model for lake recreation: a comparison of two methods for incorporating site quality and substitution effects. American Journal of Agricultural Economics 68(2): 291-297.

Cavatassi R (2004) Valuation methods for environmental benefits in forestry and watershed investment projects. ESA Working Papers, Agricultural and Development Economics Division, FAO, Rome.

Chand M (2010) A cross-national study of motivational determinants among non-resident Indian visitors to religious centers in India. International Journal of Hospitality \& Tourism Administration 11(1): 22-38.

Choi HY, Kwak SJ, Yoo SH (2016) The preservation value of the Banguadae Petroglyphs, the 285th Korean National Treasure. Journal of Cultural Hetitage 18: 380-383.

Colson F, Stenger-Letheux A (1996) Contingent assessment and agricultural landscapes: Application to the hedged farmland of Loire-Atlantique. Cahiers d'Économie et Sociologie Rurales 39-40: 151-177. (In French)

Chomitz KM, Alger K, Timothy TS, Heloisa O, PauloVila N (2005) Opportunity costs of conservation in a biodiversity hotspot: 


\section{sciendo}

The case of southern Bahia. Environment and Development Economics 10: 293-312.

Council of Europe (2000) European Landscape Convention and Explanatory Report. Council of Europe, Document by the Secretary General established by the General Directorate of Education, Culture, Sport and Youth, and Environment, Florence.

Daily GC (1997) Nature's Services: Societal Dependence on Natural Ecosystems. Island Press: Washington.

DelᄀRio JAJ, Agüera OF, Cuadra OF, Morales CP (2017) Satisfaction in border tourism: An analysis with structural equations. European Research on Management and Business Economics 23 103-112.

Demirovic' D, Berjan S, Milentijevic' N, El-Bilali H, Syromiatnikova YA (2019) Exploration of tourist motivation and preferred activities in rural areas. Journal of Geographic Institute of Cvijic 69(1): 29-37.

Frochot I (2005) A benefit segmentation of tourists in rural areas: A Scottish perspective. Tourism Management 26(3): 335-346.

Fry G, Tress B, Tress G (2007) Integrative landscape research: facts and challenges. In: Wu J, Hobbs R (eds) Key Topics in Landscape Ecology. Cambridge University Press, Cambridge.

Garrod G, Willis KG (1999) Economic Valuation of the Environment: Methods and Case Studies. Cheltenham: Edward Elgar Publications.

Greenley DA, Walsh RG, Young RA (1981) Option value: empirical evidence from a case study of recreation and water quality. The Quarterly Journal of Economics 96(4): 657-673.

Guilan Province Management and Planning Organization, Deputy of Statistics and Information (2021) Available at: <https://sdi.mpogl.ir>

Folke C, Biggs R, Norström AV, Reyers B, Rockström J (2016) Social-ecological resilience and biosphere-based sustainability science. Ecology and Society 21(3): 1-16.

Jang S, Wu CME (2006) Seniors' travel motivation and the influential factors: An examination of Taiwanese seniors. Tourism Management 27(2): 306-316.

Hanley N, Barbier E (2009) Pricing Nature: Cost-benefit Analysis and Environmental Policy. Cheltenham: Edward Elgar Publications.

Hanley N, Ready R, Colombo S, Watson F, Stewart M, Bergmann EA (2009) The impacts of knowledge of the past on preferences for future landscape change. Journal of Environmental Management 90(3): 1404-1412.

Hanemann WM (1984) Welfare evaluation in contingent valuation experiments with discrete responses. American Journal of Agricultural Economics 66: 332-341.

Hermann A, Schleifer S, Wrbka T (2011) The concept of ecosystem services regarding landscape research: A review. Living Reviews in Landscape Research 5(1): 1-37.

Hueting R, Reijnders L, de Boer B, Lambooy J, Jansen H (1998) The concept of environmental function and its valuation. Ecological Economics 25(1): 31-35.

Insch A (2020) The challenges of over-tourism facing New Zeland: Risks and responses. Journal of Destination Marketing and Management 15: 100378.

Jim C, Chen WY (2006) Recreation-amenity use and contingent valuation of urban greenspaces in Guangzhou, China. Landscape and Urban Planning 75: 81-96.
Jimenez-Garcia M, Ruiz-Chico J, Pena-Sanchez AR (2020) Landscape and tourism: Evolution of research topics. Land 9(488): $1-17$.

Kealy MJ, Turner RW (1993) A test of the equality of closed-ended and open-ended contingent valuations. American journal of agricultural economics 75: 321-331.

Kriström B (1993) Comparing continuous and discrete contingent valuation questions. Environmental and Resource Economics 3: 63-71.

Lee CK, Han SY (2002) Estimating the use and preservation values of national parks tourism resources using a contingent valuation method. Tourism Management 23: 531-540.

Liao ZHLMJ, Haung L (2015) Survey analysis on tourist satisfaction in Jiuzhaigou Valley. International journal of multimedia and ubiquitous engineering 10: 89-98.

Lifran R, Oueslati W (2007) Elements of landscape economics. Rural Economy 297-298: 85-98. (In French)

Liu X (2007) The theoretic improvement and its application of CVM in the valuation if Qixinghe wetland services. Ecological Environment 2: 317-320.

Loomis J, Kent P, Strange L, Fausch K, Covich A (2000) Measuring the total economic value of restoring ecosystem services in an impaired river basin: Results from a contingent valuation survey. Ecological Economics 33: 103-117.

Loomis J, Tadjion O, Watson PS, Wilson J, Davies S, Thilmany D (2008) A hybrid individual: zonal travel cost model for estimating the consumer surplus of golfing in Colorado. Journal of Sports Economics 10(2): 155-167.

Ma J, Sun X (2001) Review of studies on forest tourism resource evaluation. Journal of Gansu Agricultural University 36(4): 357-363.

Marta-Pedroso C, Freitas H, Domingos T (2007) Testing for the survey mode effect on contingent valuation data quality: A case study of web based versus in-person interviews. Ecological Economics 62: 388-398.

Millennium Ecosystem Assessment (2005) Ecosystems and Human Well-being: Synthesis. Island Press: Washington, DC.

Molaei-Hashjin N (2006) Geographic Landscape (concepts, definition and branches). Journal of Studies of Human Settlements Planning 1(1): 5-18.

Molera L, Albaladejo IP (2007) Profiling Segments of Tourists in Rural Areas of South-Eastern Spain. Tourism Management 28(3): 757-767.

Naidoo R, Adamowicz WL (2005) Economic benefits of biodiversity exceed costs of conservation at an African rainforest reserve. Proceedings of the National Academy of Sciences of the USA 102(46): 16712-16716.

Nijkamp P, Vindigni G, Nunes PA (2008) Economic valuation of biodiversity: A comparative study. Ecological Economics 67: 217-231.

O'riordan T, Wood C, Shadrake A (1993) Landscapes for Tomorrow. Journal of Environmental Planning and Management 36(2): 123-147.

Oueslati W, Madariaga N, Salanié J (2008) Contingent assessment of landscape amenities linked to an urban green space. An application to the case of Balzac Park in the city of Angers. Journal of studies in Agriculture and Environment 87(2): 77-99. (In French)

Park T, Loomis J (1996) Joint Estimation of Contingent Valuation Survey Responses. Environmental and Resource Economics 7: 149-162. 


\section{Sciendo}

Park DB, Yoon YS (2009) Segmentation by motivation in rural tourism: A Korean case study. Tourism Management 30(1): 99-108.

Pearce PL, Lee U (2005) Developing the travel career approach to tourism motivation. Journal of Travel Research 43(3)> 226-237.

Pesonen J, Komppula R (2010) Rural Wellbeing Tourism: Motivations and Expectations. Journal of Hospitality and Tourism Management 17(1): 150-157.

Point P, Dachary-Bernard J, Rambonilaza M, Dehez J, Lafon S, Boschet C (2007) Economic approach to the value of variations in the attributes of the rural landscape. ADER Unit, Cemagref de Bordeaux \& GRAPE-CEEP, Montesquieu Bordeaux IV University. (In French)

Preez MD, Hosking S. (2010) Estimating the recreational value of freshwater inflows into the Klein and Kwelera estuaries: an application of the zonal travel cost method. Water SA 36(5): 553-561.

Prigent L (2001) Use value and existence value of a heritage: An application of the contingent valuation method at Mont-SaintMichel. PhD Thesis, University of Western Brittany. (In French)

Prince S (2019) Dwelling and tourism: Embracing the nonrepresentational in the tourist landscape. Landscape Research 44: 731-742.

Rambonilaza M (2004) Assessment of landscape demand: state of the art and reflections on the profit transfer method. Cahiers d'Économie et Sociologie Rurales 70: 77-101. (In French)

Samdin Z (2008) Willingness to pay in Taman Negara: A Contingent Valuation Method. International Journal of Economics and Management 2(1): 81-94

Scherrer S (2001) The visual and noise damage caused by wind turbines: an assessment by the willingness to pay of households in the case of Sigean wind turbines, Ministry of Ecology and Sustainable Development: Paris. (In French)

Soltani A, Sharif HR (2016) Satisfaction Analysis of Religious Tourism Service with Emphasis on the Role of Environmental Factors, the Case Study of Shahcheragh Shrine in Shiraz. Research and Urban Planning 23: 35-54. (In Persian)

Statistical center of Iran. Report on Iran's population. 2019. Available at $><$ www.amar.org.ir/english $>$

Royo-Vela M (2009) Rural-cultural excursion conceptualization: A local tourism marketing management model based on tourist destination image measurement. Tourism Management 30(3): 419-428.

Terra S (2004) Estimation of nuisances for the community generated by Sigean wind turbines, Ministry of Ecology and Sustainable Development: Paris. (In French)
Terra S, Fleuret A (2009) Social acceptability of wind turbines: residents willingness to pay to conserve wind turbines. Survey on four French wind power plants, General Commission for Sustainable Development, Paris.

Tkac JM (2002) Estimating willingness to pay for the preservation of the Alfred Bog wetland in Ontario: a multiple bounded discrete choice approach. Master Thesis, Ottawa, McGill University.

Terkenli TS (2000) Landscape of tourism: a cultural geographical perspective. In: Briassoulis $\mathrm{H}$, van der Straaten J (eds) Tourism and the Environment: Regional, Economic, Cultural and Policy Issues, revised 2nd edition. Kluwer Academic Publishers, Dordrecht, pp. 179-202.

Turner RK, Paavola J, Cooper P, Farber S, Jessamy V, Georgiou S (2003) Valuing nature: lessons learned and future research directions. Ecological Economics 46(3): 493-510.

Turner RK, Schaafsma M (2015) Coastal zones ecosystem services: From science to values and decision making, Studies in Ecological Economics Series, Springer.

Tyrväinen L, Silvennoinen H, Nousiainen I, Tahvanainen L (2001) Rural tourism in Finland: Tourists' Expectation of Landscape and Environment. Scandinavian Journal of Hospitality and Tourism 1(2): 133-149.

Walsh RG, Loomis JB, Gillman RA (1984) Valuing option, existence, and bequest demands for wilderness. Land Economics 60(1): 14-29.

Wang W, Chen JS, Huang K (2016) Religious Tourist Motivation in Buddhist Mountain: The Case from China. Asia Pacific Journal of Tourism Research; 21(1): 57-72.

Willis KG, Garrod GD (1991) An individual travel: cost method of evaluating forest recreation. Journal of Agricultural Economics 42(1): 33-42.

Willis KG, Garrod GD (1992) Assessing the Value of Future Landscapes. Landscape and Urban Planning 23(1): 17-32.

Willis KG, Garrod GD (1993) Valuing Landscape: a Contingent Valuation Approach. Journal of Environmental Management; 37: $1-22$.

Yi X, Cheng CH, Wu Y, Zhiyun O, Enming R (2016) Evaluating value of natural landscapes in China. Chinese Geographical Science; 26(2): 244-255.

Yousefi M, Marzuki A (2015) An Analysis of Push and Pull Motivational Factors of International Tourists to Penang, Malaysia. International Journal of Hospitality \& Tourism Administration 16(1): 40-56.

Zamorshchikova L, Filippova V, Savvinova A, Samsonova M, Totonova E (2018) Recreational landscape value in tourism development of Central Yakutia. Book chapter in landscape architecture-the sense of places: models and applications: IntechOpen, London. 